\title{
Marine Microplastics in Polar Region-a Spitsbergen Case Study
}

\author{
Agnieszka Dąbrowska
}

Received: 25 October 2020 / Accepted: 6 September 2021 / Published online: 16 September 2021

(C) The Author(s) 2021

\begin{abstract}
The aim of this short paper is to report the presence of primary and secondary microplastics in Svalbard and surrounding waters. The sampling and monitoring were done during the AREX 2017 polar expedition and included the Spitsbergen (Longyearbyen, Pyramiden) and western fjords, in particular Isfjorden, Kongsfjorden. Moreover, the unique scientific trawls were carried out in Raudefjorden at the very north coast of Spitsbergen. Finally, the plastic tide effects were confirmed at the Prins Karl Forland Island.
\end{abstract}

Keywords Marine microplastic $\cdot$ Microplastic sampling device $\cdot$ Spitsbergen · Raman spectroscopy $\cdot$ Plastic pollution $\cdot$ Polar regions

Supplementary Information The online version contains supplementary material available at https://doi. org/10.1007/s11270-021-05346-2.

A. Dąbrowska $(\bowtie)$

Laboratory of Spectroscopy and Intermolecular Interactions, Faculty of Chemistry, University of Warsaw,

Pasteura 1, 02-093 Warsaw, Poland

e-mail: adabrowska@chem.uw.edu.pl

A. Dąbrowska

Biological and Chemical Research Centre, University of Warsaw, Żwirki i Wigury 101 st, 02-089 Warsaw, Poland

\section{Introduction}

Marine microplastics (MMs), the polymer materials $<5 \mathrm{~mm}$, are already ubiquitous in the global ocean (Jiang, 2018) including the remote and pristine areas of the Arctic (Hallanger \& Gabrielsen, 2018) and Antarctic (Bargagli, 2008). A total of 38-243 particles of MMs per litre were reported in multilayer sea ice (transect over the Arctic Ocean). Although the first reports on the plastic pollution in the Arctic date back to the $70 \mathrm{~s}$ and $80 \mathrm{~s}$ (Amchitka Island, Aleutian Island, Bering Sea), there is still a lack of detailed data about the amount of MMs in the polar region and so the possibilities of modelling of the flux and consequences are limited. That is why the basic environmental monitoring standard and a universal sampling protocol are urgently needed. One can find useful geospatial information and satellite data (Topouzelis et al., 2019). In the Antarctic, the MM presence was reported in the deep-sea sediments (Van Cauwenberghe et al., 2013) and the surface waters of the Southern Ocean (Waller et al., 2017) reaching locally even 117 particles per litre. In another research (Isobe et al., 2017), from 5 tows, authors collected 44 pieces and estimated the total count at two stations near Antarctica $\sim 100,000$ per $\mathrm{km}^{2}$. In the Arctic, the presence of plastics in the deepsea sediments (2500 m depth) was confirmed at the HAUSGARTEN observatory (Tekman et al., 2017). The $90 \%$ occurrence with an average of 9.5 items of MMs per individual was reported for the Arctic blue 
mussels (Mytilus edulis). The sediments of Adventfjorden (40-70 m depth) have circa 9.2 fibres per kilogram. Fishery-related items are dominant among plastics in Svalbard (cut rope, trawl nets, ghost fishing, etc.). This source is particularly harmful to biota and causes substantial by-catch and toxic pollution due to the leakage of metals and added compounds from degrading material. The beaches Brucebukta and Luftskipodden are yearly monitored by the Governor of Svalbard. Although being an evidence of the MM presence, those data available for a general public are mainly quantitative. The Polarquest Expedition reached in 2018 the $82^{\circ} 07^{\prime} \mathrm{N}$ providing the evidence of the ubiquitous plastic pollution. The presence of MMs is confirmed around the Arctic: in animals, sea ice, on the land, sediments and surrounding waters. For instance, up to 250 particles per $\mathrm{m}^{3}$ in the cores from sea ice, significant amount in the box core samples from Kuril-Kamchatka Trench, $2.9 \mathrm{~kg}$ per $\mathrm{km}^{2}$ at the seafloor of Barents Sea, 42-6595 particles per kg in Fram Strait, 0.7 MMs per $\mathrm{m}^{3}$ near the water surface and the estimated annual flux to the Arctic range from 62,000 to 105,000 tons (Halsband \& Herzke, 2019). One can point out the huge inaccuracy of those estimations what proves the need for increased sampling in this area.

The polar regions are particularly prone to the known and emerging pollutants (Corsolini, 2009) and their fragile natural equilibria are easy to be influenced if not destroyed (Kennicutt et al., 2019). There are also already visible adaptations, such as the bacteria evolving towards the decomposition of POPs (persistent organic pollutants) or plastics (Papale et al., 2017). One can focus on the polar circulation zones as the new accumulation gyres, for instance, taking into account the increasing vortex at the Barents Sea (with offshore levels around 194 items per $\mathrm{km}^{2}$ ) or the Greenland Sea Gyre (Jiang et al., 2020) with circa 2.43 items per litre. Those zones are the perfect sampling sites for the naturally weathered macroplastics and promising sites to observe the unique biofilm on MMs - the Plastisphere. In the Antarctic, the bacteria associated with polystyrene were tested (Laganà et al., 2019). Moreover, the invasive species use MM particles as transportation vectors. The exotic barnacle (Semibalanus balanoides) and bryozoan (Membranipora membranacea) were found on $7 \%$ of MMs collected in Kongsfjorden in 2002 (Hallanger \& Gabrielsen, 2018).
Furthermore, one can observe the impact of macroplastics and MMs on biota. The entanglement in derelict fishing gear was observed in reindeers and seals. In particular, the sea birds (Amélineau et al., 2016), already the most vulnerable group of species, are directly influenced by the presence of plastic items. False satiation, entanglements, mechanical injuries, stress and inflammation are just a few observed consequences. According to the OSPAR (the Convention for the Protection of the Marine Environment of the northeast Atlantic) strategic goal, Ecological Quality Objective, less than $10 \%$ of monitored fulmars (Fulmarus glacialis) should not have more than $0.1 \mathrm{~g}$ of plastics in the stomach. Currently, it is $22 \%$ for Svalbard, $28 \%$ for Iceland and $62 \%$ for the North Sea. The presence of any MMs in the stomach was confirmed in $87.5 \%$ of fulmars tested in Svalbard and $79.3 \%$ of those from Iceland. Fulmars, with an extensive foraging range, are ideal monitoring species. One can think of diverse other species as sentinels or biological indicators of MMs and pollution in the polar region, for instance, the nematode biomass and morphology in the Arctic (Grzelak et al., 2016) or albatrosses and petrel in the South Ocean (Phillips \& Waluda, 2020).

The MMs found in the Arctic can be from the primary (scrubs, textiles) or secondary sources (fragmented UV). Moreover, the phenomenon called "plastic tide" is responsible for the appearance of synthetic materials far away from their original place of deposition. Once entering the ocean system, the items circulate globally contaminating overseas lands regardless of the value of pristine habitats or the boundaries of marine protected areas. The proper sampling strategy should focus on the local conditions and their rapid changes (Skogseth et al., 2020). In constructing the global models of fate and transport of MMs, the crucial is their buoyancy and hydrophobicity. That is why the morphology of the surface and functionalization is crucial (Song et al., 2019). Local and global studies show that various types of plastics are not evenly distributed (Lorenz et al., 2019). One should think of the different sampling protocol considering the diverse behaviour of polymers and their entry paths. The important source of MMs in the Arctic is the water circulation between the polar regions and the Northeast Atlantic Ocean where the average abundance of plastics is estimated as 2.46 particles per $\mathrm{m}^{-3}$ (Lusher et al., 2014). Warmer waters exhibit a higher concentration of MMs. 
The proper MM characterization from the environmental samples is still a challenge (Silva et al., 2018). Within this paper, one analyzes the variety of primary and secondary MMs found in Spitsbergen and its coastal waters. The specially designed sampling device was successfully tested in the pelagic seawater. In previous reports, the manta $(\sim 300 \mu \mathrm{m})$ approach is the most common, as a second the pumps. Some additional unexpected MM sources were found providing the samples for laboratory analysis, for instance from the beach in Longyearbyen. The physical and chemical characterization was carried out using Raman (Philipp M. Anger et al., 2018a, b) and FTIR (Cincinelli et al., 2017) spectroscopy. Among several methods (Wang \& Wang, 2018), those two complementary techniques enable the complete physical and chemical characterization of materials (Ghosal et al., 2018) without destroying them. One should bear in mind that proper signal processing is indispensable and the data treatment significantly influences the results (Renner et al., 2019).

\section{Materials and Methods}

\subsection{Sampling Device}

A sampling of the seawater was done from its surface layer $(0-0.5 \mathrm{~m}$ depth) by the dedicated device designed and constructed to resolve the standard problems of existing solutions, such as box corers, neuston nets, manta, multinet, pumps and bucket filters (Costa et al., 2019). The main drawbacks observed were the following: high cost, lack of resistance to bad weather conditions, low reproducibility, self-contamination from synthetic materials used in the sampling device itself, large mesh size of filtration nets $(\sim 300 \mu \mathrm{m})$ not enabling the collection of the smallest fractions, clogging of elastic manta net and complicated, including a few steps, sample collection and pre-treatment (Stock et al., 2019). The proposed system (Fig. 1) consists of the stainless steel chassis (Fig. 1a) with the first chromium-nickel net of $300 \mu \mathrm{m}$ or $500 \mu \mathrm{m}$ used for pre-filtration of inorganic and organic matter. The main part of the device is the fine, disposable, with 10-20 $\mu \mathrm{m}$ of the pore diameter, the metal filter (Fig. 1c, 2) used for the proper sampling. One can perform the spectral analysis directly on it, which simplifies the laboratory protocol and decreases the risk of contamination. Moreover, there is no need for GFF (standard glass filters) which quenched the Raman signal due to the significant selffluorescence. The simplicity of the device enables its use by no specialists, for instance, sailors, thus multiplies the amount of collected data and number of repetitions during the monitoring.

The sampling device was hauled after the research vessel at a standard distance $(15,25,100 \mathrm{~m})$ and the controlled blanks were used simultaneously on board (without direct contact with the seawater, but exposed to all possible sources of the self-contamination). At this stage, the water flux was estimated from the ship movement, but the flow meter can be easily added to the equipment. Sailing logbook parameters and the water physical and chemical information were also documented. Finally, the water transparency $\geq 0.5 \mathrm{~m}$ (Table 1), which is strictly correlated with the presence of organic suspension, was an essential condition for sampling. The filters were collected after each full transect from the starboard and backboard. All samples collected were primarily tested by the optical and spectral techniques before any additional chemical treatment that might influence the morphology of a Plastisphere.

\subsection{Costal Monitoring}

As only some of the MMs in the oceans were thrown there directly and the majority was brought by freshwaters, it is crucial to map the transport of plastics coming from lands. Apart from the rivers, the litter on the beach and in the breaking wave zones are the dominant sources. Objects of synthetic materials are gradually fragmented, by UV light and mechanical abrasion, and they mean size decreases while approaching the waterline. Within this study, the plastic litter found at the beach in Longyearbyen was mapped and geotagged and the fragments measured and collected checking the size distribution. The gradual fragmentation is directly related to the weathering level and provides useful information for the further spectral description of polymers at different stages of decomposition. On the other hand, plastic tide phenomena are responsible for the migration of synthetic materials far away from the origin of pollution. The size distribution within the coastal line of 
Fig. 1 The sampling device dedicated for the collection of MMs from the surface water layer; a the internal construction, $\mathbf{b}$ at sea, (1) chromium-nickel net for a pre-filtration $(300 \mu \mathrm{m})$, (2) the central part of the sampler-a 20- $\mu \mathrm{m}$ net collecting the particles, (3) the wake during a hauling at the maximum speed a)

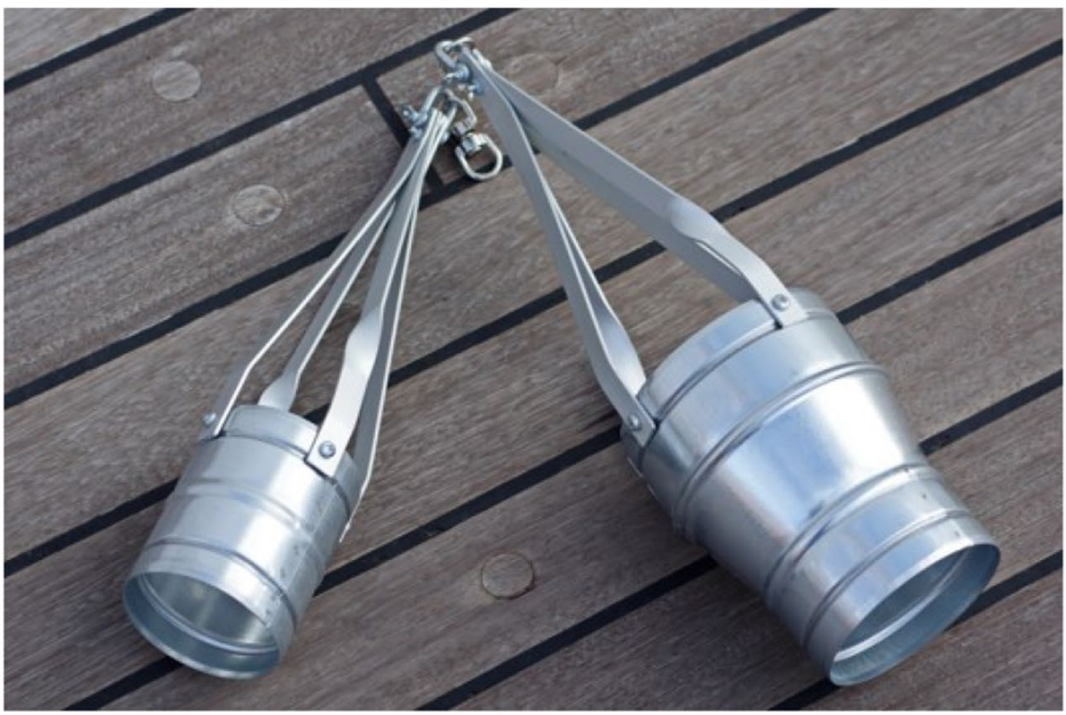

b)

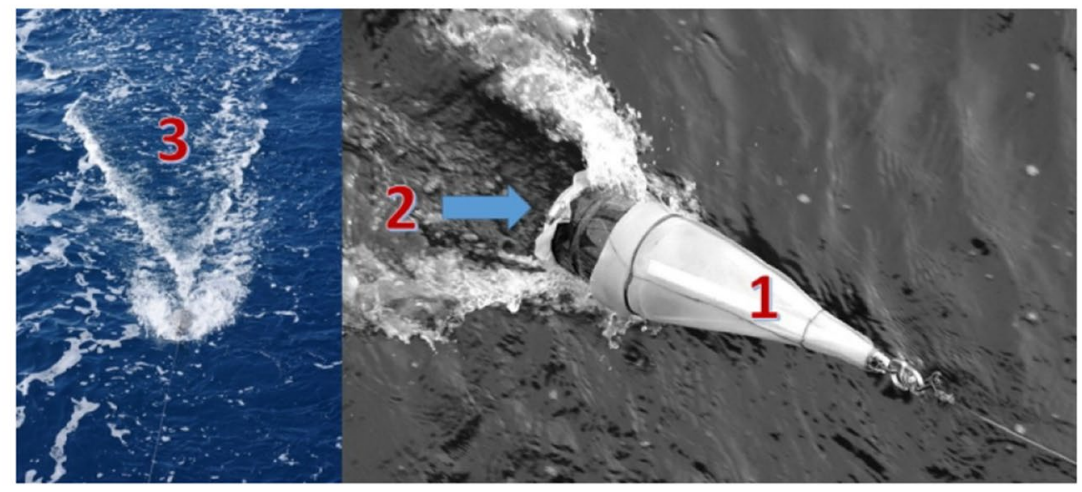

those types of materials makes one distinguish easily their remote origin. For the preliminary search of places affected by the plastic tide, the global ocean thermohaline circulation models were used together with the sailors' knowledge based on experience at those waters. One tried to use as much as possible the standard zones studied in a long period.

\subsection{Raman Spectroscopy Measurements}

As the optical microscopy is not sufficient for the proper qualitative and quantitative characterization of MMs, leading to the overestimations, the Raman spectroscopy seems indispensable (Lv et al., 2020). Within this study, the spectra were collected using DXR Raman microscopy (Thermo Scientific) with four laser lines accessible: $455 \mathrm{~nm}, 532 \mathrm{~nm}, 633 \mathrm{~nm}$ and $780 \mathrm{~nm}$. The most popular green 532-nm laser line was used if not otherwise specified. Although it is advisable to use this wavelength (as providing a stable signal easy to compare with databases), in few cases, the strong self-luminescence of the samples prevents the proper signal registration. In that case, the change in the laser wavelength was adopted or its power decreased (from the standard $10 \mathrm{~mW}$ ). That resolved the problem and enabled the qualitative identification of all macro debris. However, one should be aware of the fact that the change in a laser line significantly influences the spectra making any numerical quantitative comparison (of crystallinity or ageing) impossible. The polypropylene (PP), polyethene of high and low density (HDPE, LDPE, respectively) and polystyrene (PS) are most common from the variety of polymers found in environmental samples. The identification is based on the presence and shape of spectral bands in the range $2600-3200 \mathrm{~cm}^{-1}$. 


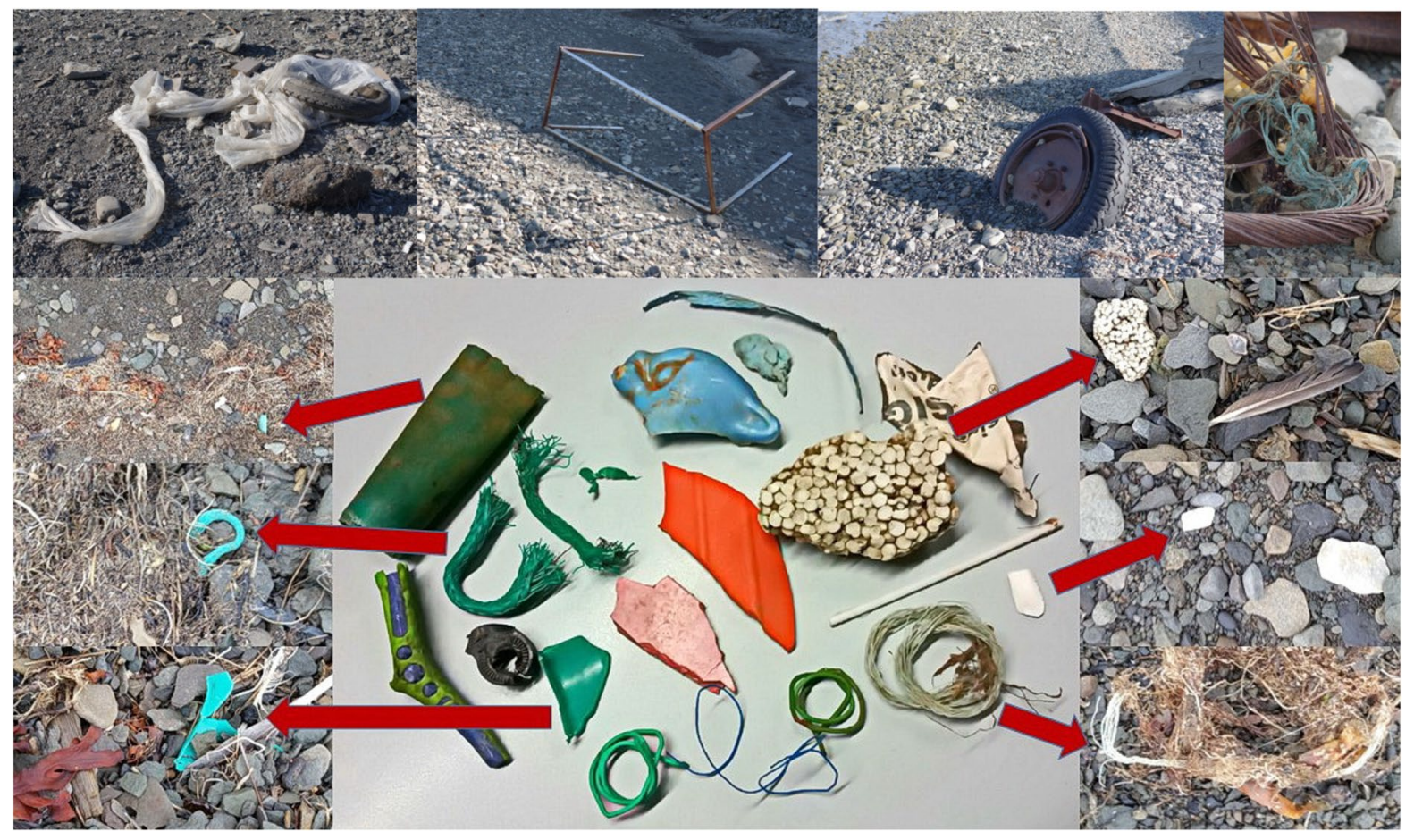

Fig. 2 Selected macro items directly discarded on a beach at Longyearbyen (upper row) and the examples of items collected for the analysis at their original places (bottom row)

Table 1 The results of water transparency measurements in sampling zones

\begin{tabular}{llll}
\hline No & Position & Data & Transparency \\
\hline 1 & $78^{\circ} 54,844^{\prime} \mathrm{N}, 07^{\circ} 53,123^{\prime} \mathrm{E}$ & 050,817 & $7 \mathrm{~m} 30 \mathrm{~cm}$ \\
2 & $79^{\circ} 02,623^{\prime} \mathrm{N}, 11^{\circ} 07,713^{\prime} \mathrm{E}$ & 060,817 & $7 \mathrm{~m} 90 \mathrm{~cm}$ \\
3 & $78^{\circ} 53,222^{\prime} \mathrm{N}, 12^{\circ} 25,703^{\prime} \mathrm{E}$ & 060,817 & $0 \mathrm{~m} 50 \mathrm{~cm}$ \\
4 & $78^{\circ} 59,554^{\prime} \mathrm{N}, 11^{\circ} 33,787^{\prime} \mathrm{E}$ & 070,817 & $2 \mathrm{~m} 40 \mathrm{~cm}$ \\
5 & $78^{\circ} 55,495^{\prime} \mathrm{N}, 12^{\circ} 22,503^{\prime} \mathrm{E}$ & 080,817 & $1 \mathrm{~m} \mathrm{00} \mathrm{cm}$ \\
6 & $79^{\circ} 39,064^{\prime} \mathrm{N}, 11^{\circ} 03,078^{\prime} \mathrm{E}$ & 090,817 & $5 \mathrm{~m} \mathrm{00} \mathrm{cm}$ \\
7 & $79^{\circ} 42,075^{\prime} \mathrm{N}, 12^{\circ} 14,035^{\prime} \mathrm{E}$ & 100,817 & $2 \mathrm{~m} 10 \mathrm{~cm}$ \\
8 & $78^{\circ} 14,092^{\prime} \mathrm{N}, 15^{\circ} 35,174^{\prime} \mathrm{E}$ & 110,817 & $3 \mathrm{~m} 50 \mathrm{~cm}$ \\
9 & $78^{\circ} 26,399^{\prime} \mathrm{N}, 15^{\circ} 59,085^{\prime} \mathrm{E}$ & 120,817 & $\sim 2 \mathrm{~m}$ \\
\hline
\end{tabular}

Their occurrence is due to the $-\mathrm{CH}_{2}$ and $-\mathrm{CH}_{3}$ groups. Apart from the qualitative analyses, the quantitative description is possible as one can use the relative ratio of intensities to monitor the general weathering of the material. The $-\mathrm{CH}_{3}$ amount will increase systematically during the carbon chain fragmentation. For analyzing the general condition of materials, the spectral range below $1500 \mathrm{~cm}^{-1}$ is useful. One can even determine the PE density (proportional to the level of crystallinity in the material) increasing with the ratio of the following bands: the asymmetric $\mathrm{CH}_{2}$ stretching $2882 \mathrm{~cm}^{-1}$ to the symmetric stretching at $\sim 2848 \mathrm{~cm}^{-1}$. Similarly, in the $\mathrm{CH}_{2}$ bending region, the ratio of peaks around $1416 \mathrm{~cm}^{-1}$ to those at $1440 \mathrm{~cm}^{-1}$ (crystal to amorphous) can be determined.

In general, the identification of at least eleven most common polymer types is efficient, fast, well described in the literature and, in some cases, even automatic as implemented in the algorithms. Within this study, the search of debris on the filter, collecting signal and identification was done manually. The dedicated databases for MMs (from the Laboratory of Spectroscopy and Intermolecular Interactions, UW) were used for the identification and compared with those implemented in the OMNIC software.

\subsection{FTIR Mapping}

FTIR spectroscopy, being complementary to the Raman technique, is also frequently used in standard research on MMs. The signal from functional groups 
and their vibrations might be strong in one and weak in a second method. Although FTIR is normally used to provide additional information about main bands, here the Raman spectroscopy was sufficient for the proper material identification. The main advantage of infrared spectra was in the possibility of mapping and registrations of 3D representations and visualisations of samples. The IR microscopy (Thermo Scientific Nicolet iN10MX) was used in a reflectance mode, with a cooled detector dedicated for mapping. It provided a spatial resolution of $2-5 \mu \mathrm{m}$. Within this study, FTIR was used mainly for the primary microplastic detection on chromium-nickel filters, as in those samples the Raman spectra exhibited high background. It was also the cross-check of the Raman spectroscopy result that confirmed no additional microplastics except those already mapped in blanks.

\section{Results and Discussion}

\subsection{Macroplastics as a Source of the Secondary Marine Microplastics}

The macroplastic pollution was found at the beach in Longyearbyen (Fig. 2), along the coastline of Adventfjorden and Istfjorden. It included the whole objects as well as their recognizable fragments and the variety of small pieces. The linear average size of synthetic materials systematically decreased while approaching the sea. That pattern implicates that the origin of contamination is local and not due to the effect of the plastic tide. Noted pollution was in direct proximity of nesting sea birds, in particular, the barnacle goose (Branta leucopsis) and its chicks.

Breaking water zones are usually favourable for weathering studies as they usually provide the same material already at different stages of deterioration. The impact of saltwater and mechanical interactions is larger near the sea. The smallest collected fraction was already in the range of microplastics. All samples collected were in the range $5 \mathrm{~cm}-1 \mathrm{~mm}$.

The documentation of plastic pollution was carried out at the sampling site, on a distance from two waypoints: $78^{\circ} 13^{\prime} 22,64,585^{\prime \prime} \mathrm{N}, 15^{\circ} 40^{\prime}$ $17,95,523^{\prime \prime} \mathrm{E}$ and $78^{\circ} 13^{\prime} 24,27,622^{\prime \prime} \mathrm{N}, 15^{\circ} 40^{\prime}$ $9,89,252^{\prime \prime}$ E. The collected items included rope filaments, fibres, green, orange, blue, white and pink deteriorated fragments, foams, pieces of the toothbrush, garden hose and unknown origin, lollypop stick, isolations of cables and wires. The density of items was $>20$ for a standard meter of a sea coastline. For the documented part of the beach in Longyearbyen, the observed and collected items were divided into the classes and the representants of each of them further analysed by the spectral techniques. The results from Raman spectroscopy (Fig. 3) identified the following proportion between the polymer types 6:5:3:2:1 for the PE, PP, PS, PVC and LDPE (PE signal with the low crystallinity parameter and the characteristic fluorescence around $2000 \mathrm{~cm}^{-1}$ ).

Fibres and nets were from PP and PE, PS formed foams and light materials and pieces of wires and the PVC isolation and the red debris was identified as probably the LDPE. Apart from the characteristic bands enabling the qualitative description, one can observe the slight differences in peaks within the same classes due to the various dyes, plasticizers and weathering stage. Usually, more decomposed materials exhibit the increased fluorescence, broader peaks and the decreasing proportion ratio between the intensities of $-\mathrm{CH}_{2}$ to $-\mathrm{CH}_{3}$ bands. Those effects are related to the fragmentation of the polymer chain, leakage of added compounds and enhanced disorder in morphology. One can observe also the slight changes in the Raman shift.

\subsection{Plastic Tide in the Arctic}

The land expedition conducted by J. M. Węsławski on Prins Karl Forland Island reported the presence of a variety of polymer litter in a nature reserve, at the beach (Węsławski \& Kotwicki, 2018). The plastics seem to be vectors for the boreal species transportation. From their number, type and state of fragmentation and decomposition, one can conclude that they are the effect of the plastic tide. This phenomenon enables the transport of debris to remote parts of the globe, far away from their discarding zone. According to numerical modelling, in the case of the pollution at Forlandet, the origin was in Western Europe. The preliminary model of dynamics included the possibility of the Arctic Garbage Path formation, which is at this stage already confirmed by the gear at the Barents Sea. This is one of the scarce pieces of evidence of the occurrence of a plastic tide in the Arctic. 
Fig. 3 The Raman spectra and optical microscopy picture of the selected classes of plastic items from the Longyearbyen beach
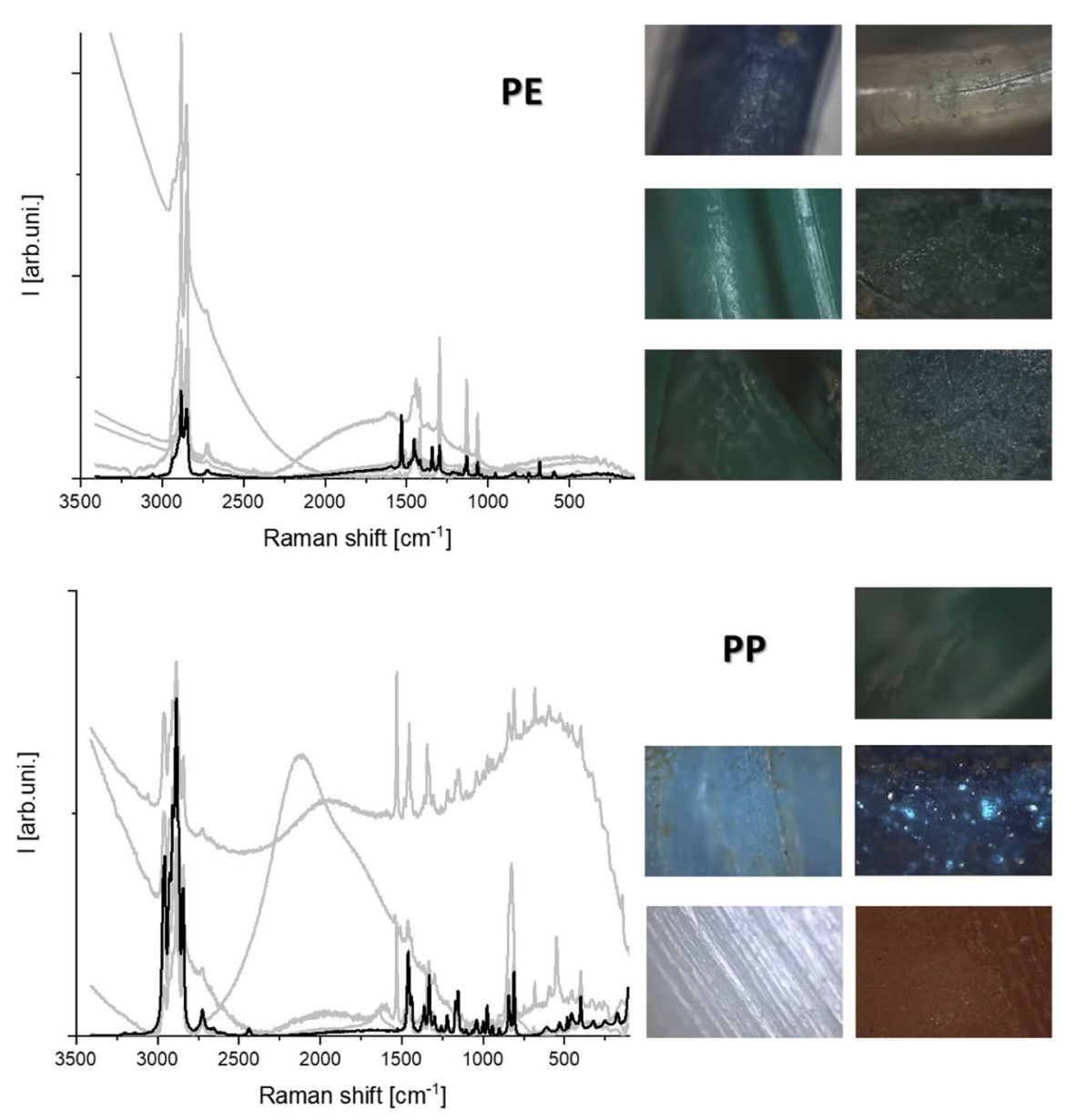

\subsection{The Primary Microplastics}

Exactly as in the other geographical location, the vast majority of microplastics collected in trawls from seawater consists of the primary MMs (Lei et al., 2017). However, in this study, the confirmed polymer debris was classified as a self-contamination (from the ship and human activities). The sampling was done by the presented device and included the hauling and one performed at "hot spots". All lists of places are included in Table 2.

Although the fibres and peeling scrub particles are usually dominant, those different from the blanks were not confirmed in the collected samples. Due to the lack of flow meter and the scarcity of data, it is impossible at this stage to estimate the concentration of MMs in the Arctic fjords. Among the filtered material, one can distinguish the majority of carbon, organic matter and metals. The FTIR mapping enables the distinction of various classes of objects specific to the area (Fig. 4). Apart from them, the polymer MMs were found (such as the paint dust or fibres from textiles), but their existence was attributed to the self-contamination as all of them were present also in blanks. One can point out that almost every human activity (including the shipping through) is a potential source of microplastics. The FTIR samples were attributed to microplastics if exhibited at least one of the bands characteristic for $-\mathrm{CH}_{2}$ groups.

Unfortunately, at this stage, any quantitative extrapolations would be premature. Also in previous research of another research team, no MMs were found in subsurface samples in Adventfjorden and Kongsfjorden (Sundet et al., 2017) what does not exclude their presence as being confirmed inside Isfjorden and in Bay Breibogen. However, one can conclude that the sediment monitoring is much better and provides more authoritative results than a surface 
Fig. 3 (continued)
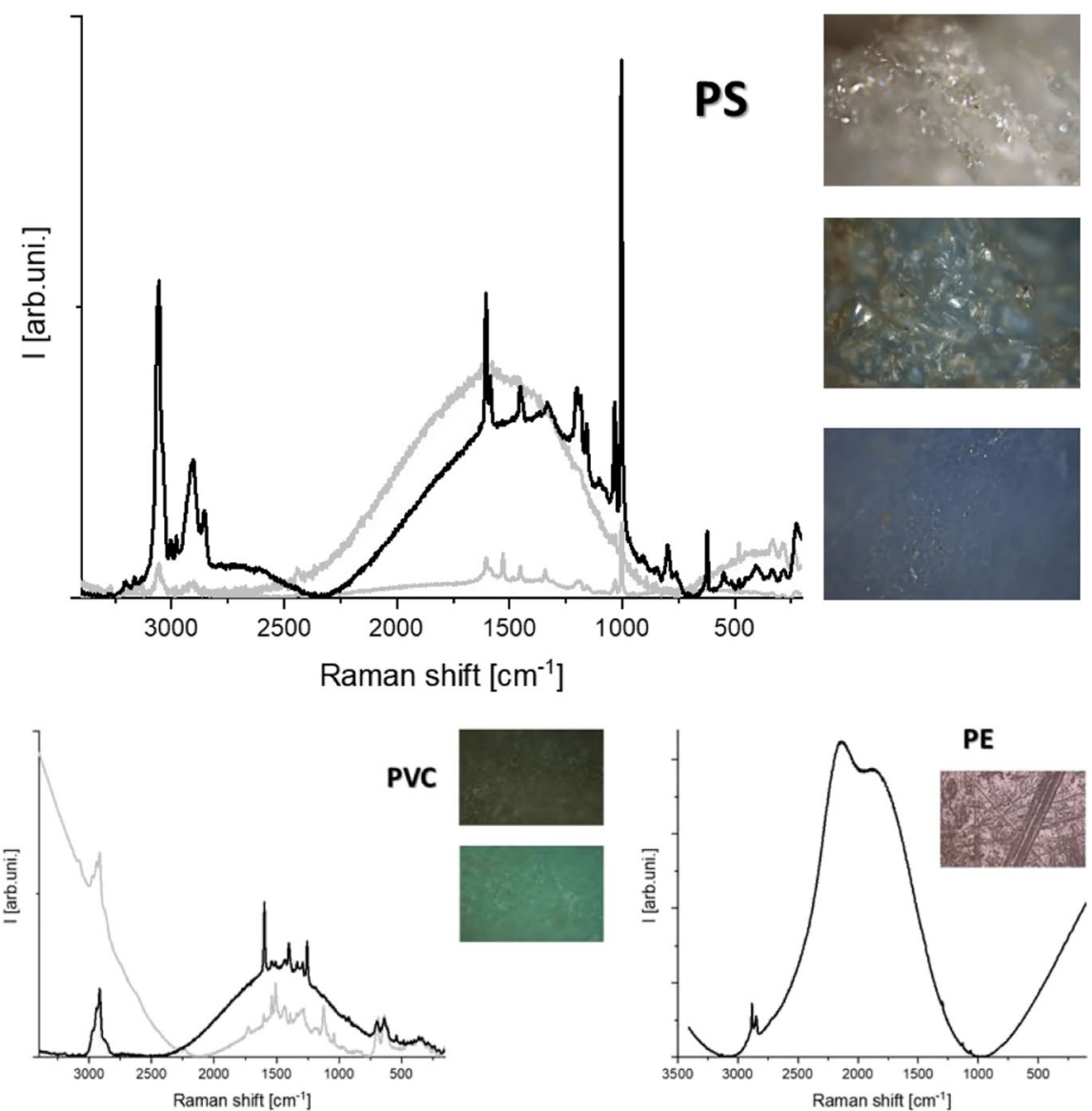

Table 2 The MM sampling locations and transects for hauling

$78^{\circ} 54,844^{\prime} \mathrm{N}, 07^{\circ} 53,123^{\prime} \mathrm{E} ; 78^{\circ} 56,110^{\prime} \mathrm{N}, 08^{\circ} 32,225^{\prime} \mathrm{E} ; 78^{\circ} 55,894^{\prime} \mathrm{N}, 08^{\circ} 32,236^{\prime} \mathrm{E} ; 79^{\circ} 02,623^{\prime} \mathrm{N}, 11^{\circ} 07,713^{\prime} \mathrm{E} ; 78^{\circ} 53,222^{\prime}$ $\mathrm{N}, 12^{\circ} 25,703^{\prime} \mathrm{E} ; 78^{\circ} 54,133^{\prime} \mathrm{N}, 12^{\circ} 17,941^{\prime} \mathrm{E} ; 78^{\circ} 57,747^{\prime} \mathrm{N}, 11^{\circ} 59,453^{\prime} \mathrm{E} ; 78^{\circ} 59,892^{\prime} \mathrm{N}, 1^{\circ} 59,006^{\prime} \mathrm{E} ; 78^{\circ} 59,554^{\prime} \mathrm{N}, 11^{\circ}$ $33,787^{\prime} \mathrm{E} ; 78^{\circ} 58,882^{\prime} \mathrm{N}, 11^{\circ} 23,311^{\prime} \mathrm{E} ; 7^{\circ} 53,549^{\prime} \mathrm{N}, 1^{\circ} 28,773^{\prime} \mathrm{E} ; 78^{\circ} 53,078^{\prime} \mathrm{N}, 12^{\circ} 25,524^{\prime} \mathrm{E} ; 7^{\circ} 55,495^{\prime} \mathrm{N}, 1^{\circ} 22,503^{\prime}$ $\mathrm{E} ; 78^{\circ} 58,286^{\prime} \mathrm{N}, 12^{\circ} 22,167^{\prime} \mathrm{E} ; 79^{\circ} 39,064^{\prime} \mathrm{N}, 11^{\circ} 03,078^{\prime} \mathrm{E} ; 79^{\circ} 53,765^{\prime} \mathrm{N}, 1^{\circ} 49,389^{\prime} \mathrm{E} ; 79^{\circ} 52,454^{\prime} \mathrm{N}, 1^{\circ} 52,025^{\prime} \mathrm{E} ; 79^{\circ}$ $45,051^{\prime} \mathrm{N}, 11^{\circ} 58,410^{\prime} \mathrm{E} ; 79^{\circ} 42,075^{\prime} \mathrm{N}, 12^{\circ} 14,035^{\prime} \mathrm{E} ; 78^{\circ} 54,248^{\prime} \mathrm{N}, 10^{\circ} 26,524^{\prime} \mathrm{E} ; 78^{\circ} 14,092^{\prime} \mathrm{N}, 15^{\circ} 35,174^{\prime} \mathrm{E} ; 7^{\circ} 14,081^{\prime} \mathrm{N}$, $15^{\circ} 35,047^{\prime} \mathrm{E} ; 78^{\circ} 14,267^{\prime} \mathrm{N}, 15^{\circ} 38,544^{\prime} \mathrm{E} ; 78^{\circ} 26,369^{\prime} \mathrm{N}, 15^{\circ} 59,128^{\prime} \mathrm{E} ; 78^{\circ} 26,399^{\prime} \mathrm{N}, 15^{\circ} 59,085^{\prime} \mathrm{E}$

from $78^{\circ} 54,542^{\prime} \mathrm{N}, 07^{\circ} 48,946^{\prime} \mathrm{E}$ to $78^{\circ} 56,110^{\prime} \mathrm{N}, 08^{\circ} 32,225^{\prime} \mathrm{E}$; from $78^{\circ} 59,160^{\prime} \mathrm{N}, 09^{\circ} 45,843^{\prime} \mathrm{E}$ to $79^{\circ} 02,623^{\prime} \mathrm{N}, 11^{\circ} 07,713^{\prime} \mathrm{E}$; from $78^{\circ} 57,469^{\prime} \mathrm{N}, 12^{\circ} 01,225^{\prime} \mathrm{E}$ to $78^{\circ} 57,488^{\prime} \mathrm{N}, 12^{\circ} 01,015^{\prime} \mathrm{E}$; from $78^{\circ} 59,892^{\prime} \mathrm{N}, 11^{\circ} 59,006^{\prime} \mathrm{E}$ to $78^{\circ} 59,554^{\prime} \mathrm{N}, 11^{\circ} 33,787^{\prime} \mathrm{E}$; from $79^{\circ} 02,262^{\prime} \mathrm{N}, 11^{\circ} 39,675^{\prime} \mathrm{E}$ to $79^{\circ} 02,131^{\prime} \mathrm{N}, 11^{\circ} 42,360^{\prime} \mathrm{E}$; from $78^{\circ} 59,430^{\prime} \mathrm{N}, 11^{\circ} 24,237^{\prime} \mathrm{E}$ to $79^{\circ} 03,14^{\prime} \mathrm{N}, 11^{\circ} 36,366^{\prime} \mathrm{E}$; from $79^{\circ} 01,240^{\prime} \mathrm{N}, 11^{\circ} 48,759^{\prime} \mathrm{E}$ to $78^{\circ} 58,510^{\prime} \mathrm{N}, 11^{\circ} 39,601^{\prime} \mathrm{E}$; from $78^{\circ} 58,510^{\prime} \mathrm{N}, 11^{\circ} 39,601^{\prime} \mathrm{E}$ to $78^{\circ} 55,208^{\prime} \mathrm{N}, 12^{\circ} 06,103^{\prime} \mathrm{E}$; from $78^{\circ} 53,549^{\prime} \mathrm{N}, 12^{\circ} 28,773^{\prime} \mathrm{E}$ to $78^{\circ} 53,078^{\prime} \mathrm{N}, 12^{\circ} 25,524^{\prime} \mathrm{E}$; from $78^{\circ} 53,078^{\prime} \mathrm{N}, 12^{\circ} 25,524^{\prime} \mathrm{E}$ to $78^{\circ} 55,495^{\prime} \mathrm{N}, 12^{\circ} 22,503^{\prime} \mathrm{E}$; from $79^{\circ} 53,765^{\prime} \mathrm{N}, 11^{\circ} 49,389^{\prime} \mathrm{E}$ to $79^{\circ} 52,454^{\prime} \mathrm{N}, 11^{\circ} 52,025^{\prime} \mathrm{E}$ 

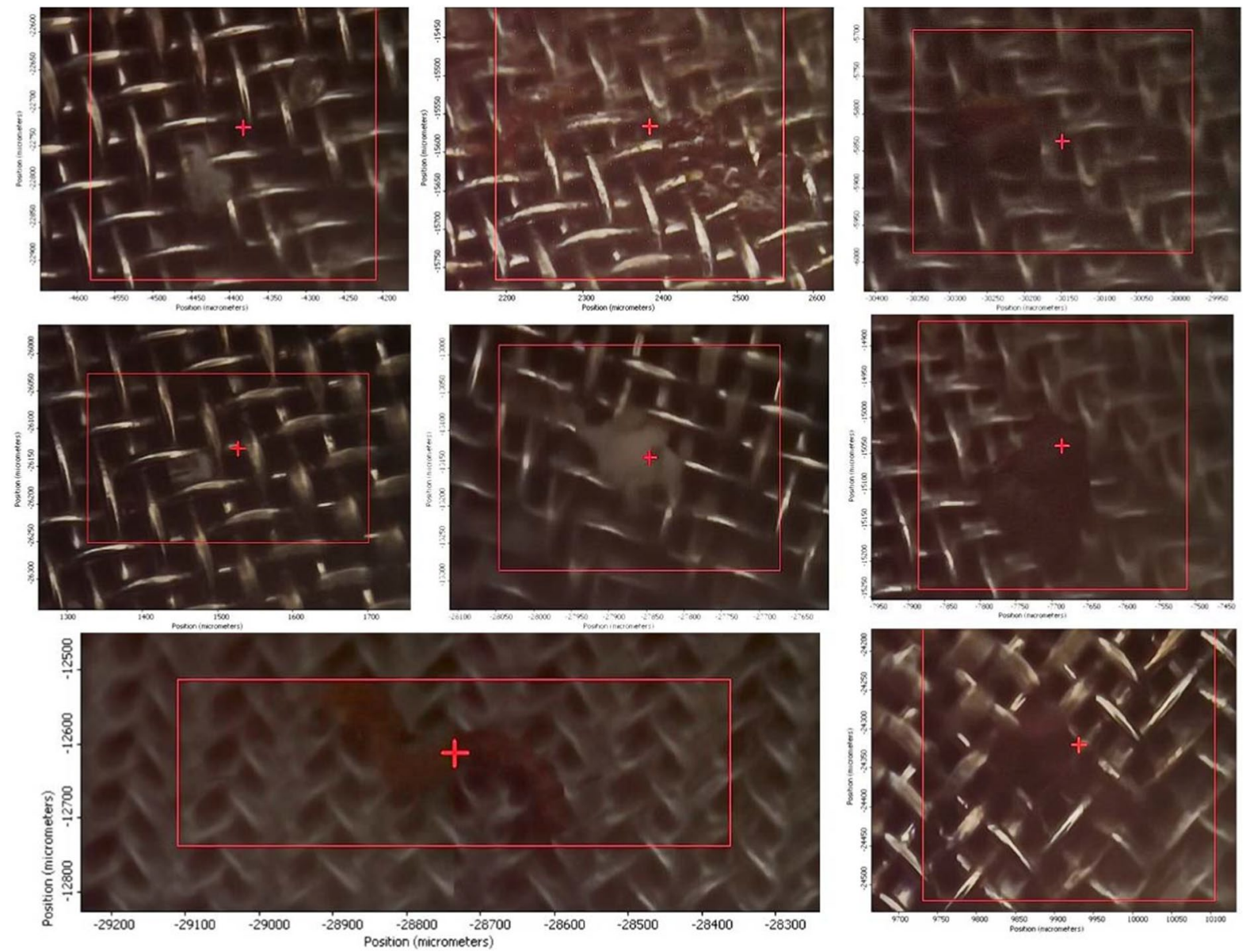

Fig. 4 The FTIR mapping of the objects fished out from the Spitsbergen fjords; dominant classes were of the natural origin (organic matter, rust, metals, sand)

layer sampling due to the less changeable external parameters (wind conditions, sea state, depth, water flux, currents, etc.). The most important would be to monitor the area in the convergence zones and check the tested zones in other seasons. Moreover, the sampling from surface water will be the most accurate for PP, PE or EPS (expanded polystyrene). In contrary, the plastic pieces of neutral or negative buoyancy (for instance PET, PLA, PS, PHA) would be more efficiently monitored in sediments from the sea floor.

\section{Conclusions, Final Remarks and Future Perspectives}

Although preliminary, the obtained results confirm the presence of marine microplastics even in the remote zone of Svalbard, Arctic. All three types of MMs, primary, secondary and a "hot spot" of a plastic tide, are reported. The research vessel itself is already a considerable source of plastic pollution. Future research should provide the details about concentrations and include flow meter data from the sampling, seasonal monitoring and possible changes correlated with the global circulations, decomposition models, information about the biofilm on the debris surface and the numerical description of the Plastisphere. Being aware of some drawbacks in the methodology, which has developed significantly since 2017 , one considers those data a valuable piece of information and a starting point for more detailed research. Moreover, regarding the presence of microplastics in the vicinity of the corresponding macrowastes, one can assume that, cognately, the nanoplastic contamination 
will be the easiest to spot in the proximity of MMs. Thus, microplastic "hot spots" can be treated as the indicators of proper places to sample the emerging and challenging analytically contaminant-nanoplastic. The Raman and nanoRaman (Lv et al., 2020) provide already sufficient spatial resolution to make those research possible (Philipp M Anger et al., 2018a, b; Sobhani et al., 2020). Finally, the electrochemical approach (cyclic voltammetry) will be useful to monitor the leakage of added compounds from synthetic materials.

Acknowledgements The author would like to thank Professor Jan Marcin Węsławski and all researchers and crew members on board r/v Oceania during the AREX 2017 expedition.

\section{Availability of Data and Material Not applicable.}

Code Availability Not applicable.

\section{Declarations}

Competing Interests The author declares no competing interests.

Open Access This article is licensed under a Creative Commons Attribution 4.0 International License, which permits use, sharing, adaptation, distribution and reproduction in any medium or format, as long as you give appropriate credit to the original author(s) and the source, provide a link to the Creative Commons licence, and indicate if changes were made. The images or other third party material in this article are included in the article's Creative Commons licence, unless indicated otherwise in a credit line to the material. If material is not included in the article's Creative Commons licence and your intended use is not permitted by statutory regulation or exceeds the permitted use, you will need to obtain permission directly from the copyright holder. To view a copy of this licence, visit http://creativecommons.org/licenses/by/4.0/.

\section{References}

Amélineau, F., et al. (2016). Microplastic pollution in the Greenland Sea: Background levels and selective contamination of planktivorous diving seabirds. Environmental Pollution, 219, 1131-1139. https://doi.org/10.1016/j. envpol.2016.09.017

Anger, P. M., et al. (2018a). Raman microspectroscopy as a tool for microplastic particle analysis, TrAC - Trends in Analytical Chemistry. Elsevier Ltd, 109, 214-226. https:// doi.org/10.1016/j.trac.2018.10.010

Anger, P. M., et al. (2018b). Trends in analytical chemistry Raman microspectroscopy as a tool for microplastic particle analysis, Trends in Analytical Chemistry. Elsevier Ltd, 109, 214-226. https://doi.org/10.1016/j.trac.2018.10.010
Bargagli, R. (2008) Environmental contamination in Antarctic ecosystems, Science of the Total Environment. Elsevier B.V., 400(1-3), pp. 212-226. doi: https://doi.org/10. 1016/j.scitotenv.2008.06.062.

Cincinelli, A., et al. (2017). Microplastic in the surface waters of the Ross Sea (Antarctica): Occurrence, distribution and characterization by FTIR, Chemosphere. Elsevier Ltd, 175, 391-400. https://doi.org/10.1016/j.chemosphere. 2017.02.024

Corsolini, S. (2009). Industrial contaminants in Antarctic biota. Journal of Chromatography A, 1216(3), 598-612. https:// doi.org/10.1016/j.chroma.2008.08.012

Costa, P., et al. (2019). Trends in Analytical Chemistry Methods for Sampling and Detection of Microplastics in Water and Sediment: A Critical Review Density Separation, 110, 150-159. https://doi.org/10.1016/j.trac.2018. 10.029

Ghosal, S., et al. (2018). Molecular identification of polymers and anthropogenic particles extracted from oceanic water and fish stomach - A Raman micro-spectroscopy study, Environmental Pollution. Elsevier Ltd, 233, 1113-1124. https://doi.org/10.1016/j.envpol.2017.10. 014

Grzelak, K., et al. (2016). Nematode biomass and morphometric attributes as biological indicators of local environmental conditions in Arctic fjords, Ecological Indicators. Elsevier Ltd, 69, 368-380. https://doi.org/10. 1016/j.ecolind.2016.04.036

Hallanger, I. G. and Gabrielsen, G. W. (2018) Plastic in the European Arctic, Norwegian Polar Institute, pp. 1-28. Available at: https://data.npolar.no/publication/586ec fcc-676c-4cd1-b552-2aa43241f3e0.

Halsband, C., \& Herzke, D. (2019). Plastic litter in the European Arctic: What do we know?, Emerging Contaminants. Elsevier Ltd, 5, 308-318. https://doi.org/10. 1016/j.emcon.2019.11.001

Isobe, A., et al. (2017). Microplastics in the Southern Ocean. Marine Pollution Bulletin. the Authors, 114(1), 623-626. https://doi.org/10.1016/j.marpolbul.2016.09.037

Jiang, J. Q. (2018) Occurrence of microplastics and its pollution in the environment: A review, Sustainable Production and Consumption. Elsevier B.V., 13(August), pp. 16-23. doi: https://doi.org/10.1016/j.spc.2017.11.003.

Jiang, Y. et al. (2020) Greenland Sea Gyre increases microplastic pollution in the surface waters of the Nordic Seas, Science of the Total Environment. Elsevier B.V., 712, p. 136484. doi: https://doi.org/10.1016/j.scitotenv.2019. 136484.

Kennicutt, M. C., et al. (2019). Sustained Antarctic research: A 21st century imperative. One Earth, 1(1), 95-113. https:// doi.org/10.1016/j.oneear.2019.08.014

Kögel, T. et al. (2020). Micro- and nanoplastic toxicity on aquatic life: Determining factors, Science of the Total Environment, 709(5817). doi: https://doi.org/10.1016/j. scitotenv.2019.136050.

Laganà, P., et al. (2019). Do plastics serve as a possible vector for the spread of antibiotic resistance? First insights from bacteria associated to a polystyrene piece from King George Island (Antarctica), International Journal of Hygiene and Environmental Health. Elsevier, 222(1), 89-100. https://doi.org/10.1016/j.ijheh.2018.08.009 
Lei, K., et al. (2017). Microplastics releasing from personal care and cosmetic products in China. Marine Pollution Bulletin. Elsevier, 123(1-2), 122-126. https://doi.org/10. 1016/j.marpolbul.2017.09.016

Lorenz, C., et al. (2019). Spatial distribution of microplastics in sediments and surface waters of the southern North Sea. Environmental Pollution, 252, 1719-1729. https://doi.org/ 10.1016/j.envpol.2019.06.093

Lusher, A. L., et al. (2014). Microplastic pollution in the Northeast Atlantic Ocean: Validated and opportunistic sampling. Marine Pollution Bulletin. Elsevier Ltd, 88(12), 325-333. https://doi.org/10.1016/j.marpolbul.2014.08. 023

Lv, L. et al. (2020) Science of the total environment in situ surface-enhanced Raman spectroscopy for detecting microplastics and nanoplastics in aquatic environments, Science of the Total Environment. Elsevier B.V., 728, p. 138449. doi: https://doi.org/10.1016/j.scitotenv.2020.138449.

Miao, L., et al. (2019). Acute effects of nanoplastics and microplastics on periphytic biofilms depending on particle size, concentration and surface modification. Environmental Pollution. Elsevier Ltd, 255, 113300. https://doi.org/10. 1016/j.envpol.2019.113300

Papale, M., et al. (2017). Enrichment, isolation and biodegradation potential of psychrotolerant polychlorinated-biphenyl degrading bacteria from the Kongsfjorden ( Svalbard Islands, High Arctic Norway ) is. Marine Pollution Bulletin. Elsevier Ltd, 114(2), 849-859. https://doi.org/10. 1016/j.marpolbul.2016.11.011

Phillips, R. A., \& Waluda, C. M. (2019). Albatrosses and petrels at South Georgia as sentinels of marine debris input from vessels in the southwest Atlantic Ocean. Environment International. Elsevier, 136(December 2019), 105443. https://doi.org/10.1016/j.envint.2019.105443

Renner, G., et al. (2019). Data preprocessing \& evaluation used in the microplastics identification process: A critical review \& practical guide, TrAC - Trends in Analytical Chemistry. Elsevier Ltd, 111, 229-238. https://doi.org/10. 1016/j.trac.2018.12.004

Saavedra, J., Stoll, S. and Slaveykova, V. I. (2019). Influence of nanoplastic surface charge on eco-corona formation, aggregation and toxicity to freshwater zooplankton, Environmental Pollution. Elsevier Ltd, 252. 715-722.https:// doi.org/10.1016/j.envpol.2019.05.135

Sendra, M. et al. (2020). Nanoplastics: From tissue accumulation to cell translocation into Mytilus galloprovincialis hemocytes. Resilience of immune cells exposed to nanoplastics and nanoplastics plus Vibrio splendidus combination, Journal of Hazardous Materials. Elsevier, 388(November 2019), p. 121788. https://doi.org/10. 1016/j.jhazmat.2019.121788.

Silva, A. B., et al. (2018). Microplastics in the environment: Challenges in analytical chemistry - A review. Analytica Chimica Acta, 1017, 1-19. https://doi.org/10.1016/j.aca. 2018.02.043
Skogseth, R., et al. (2020). Variability and decadal trends in the Isfjorden (Svalbard) ocean climate and circulation - An indicator for climate change in the European Arctic. Progress in Oceanography. Elsevier, 187(January), 102394. https://doi.org/10.1016/j.pocean.2020.102394

Sobhani, Z. et al. (2020). Identification and visualisation of microplastics/nanoplastics by Raman imaging (i): Down to $100 \mathrm{~nm}$, Water Research, 174.https://doi.org/10.1016/j. watres.2020.115658

Song, Z. et al. (2019) Fate and transport of nanoplastics in complex natural aquifer media: Effect of particle size and surface functionalization, Science of the Total Environment. Elsevier B.V., 669, pp. 120-128. doi: https://doi. org/10.1016/j.scitotenv.2019.03.102.

Stock, F., et al. (2019). Sampling techniques and preparation methods for microplastic analyses in the aquatic environment - A review. TrAC - Trends in Analytical Chemistry, 113, 84-92. https://doi.org/10.1016/j.trac.2019.01.014

Tekman, M. B., Krumpen, T., \& Bergmann, M. (2017). Marine litter on deep Arctic seafloor continues to increase and spreads to the North at the HAUSGARTEN observatory, Deep-Sea Research Part I: Oceanographic Research Papers. Elsevier Ltd, 120(June 2016), 88-99. https://doi. org/10.1016/j.dsr.2016.12.011

Topouzelis, K., Papakonstantinou, A., \& Garaba, S. P. (2019). Detection of floating plastics from satellite and unmanned aerial systems (Plastic Litter Project 2018), International Journal of Applied Earth Observation and Geoinformation. Elsevier, 79(March), 175-183. https://doi.org/10. 1016/j.jag.2019.03.011

Van Cauwenberghe, L., et al. (2013). Microplastic pollution in deep-sea sediments, Environmental Pollution. Elsevier Ltd, 182, 495-499. https://doi.org/10.1016/j.envpol.2013. 08.013

Waller, C. L., et al. (2017). Microplastics in the Antarctic marine system: An emerging area of research. Science of the Total Environment, 598, 220-227. https://doi.org/10. 1016/j.scitotenv.2017.03.283

Wang, W., \& Wang, J. (2018). Investigation of microplastics in aquatic environments: An overview of the methods used, from field sampling to laboratory analysis, TrAC - Trends in Analytical Chemistry. Elsevier Ltd, 108, 195-202. https://doi.org/10.1016/j.trac.2018.08.026

Węsławski, J. M., \& Kotwicki, L. (2018). Macro-plastic litter, a new vector for boreal species dispersal on Svalbard. Polish Polar Research, 39(1), 165-174. https://doi.org/10. 24425/118743

Publisher's Note Springer Nature remains neutral with regard to jurisdictional claims in published maps and institutional affiliations. 